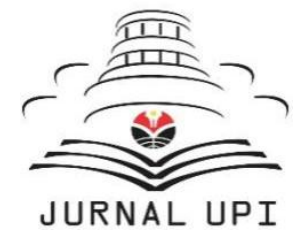

THE JOURNAL GASTRONOMY TOURISM

Volume 7 Issue 2, December 2020, 74-79

Available online at:

https://ejournal.upi.edu/index.php/gastur

Gastronomy Tourism Journal

\title{
Traditional Fish Gangan: An Icon of Gastronomic Tourism from Belitung Island
}

\author{
Yunisti Pratiwi \\ College of Tourism Ambarrukmo, STIPRAM Campus, Ahmad Yani street, $52 b$ Eastern Ring \\ Road, Ring Road East, Yogyakarta, Indonesia \\ *Corresponding Author. E-mail: yunistipratiwi@gmail.com (Yunisti Pratiwi)
}

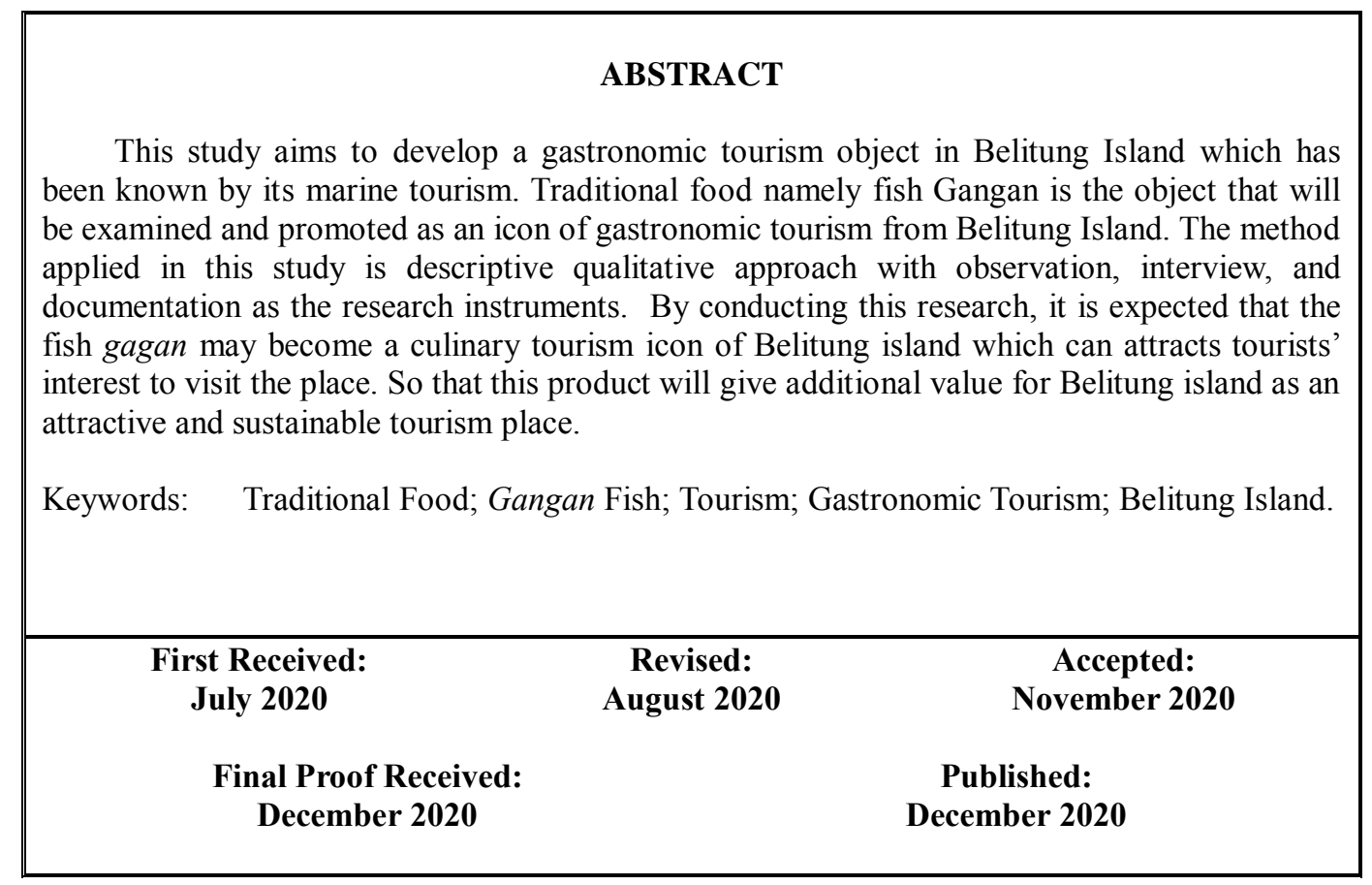

\section{Introduction}

Tourist attraction is an interesting thing that attracts tourists to visit an area. The attraction is usually objects that rarely occur and are found in their daily life (Moch.Nur Syamsu 2018: 75). Indonesia is a country that has a large tourism potential where many beautiful natural places with various and unique cultural diversities are exist. In addition, Indonesian people are mostly recognized as humble, friendly, and polite persons by international tourists.
Indonesia is one of the largest archipelago countries in the world, the Coordinating Ministry for Maritime Affairs and Investment noted that until December 2019 the numbers of islands which have been validated and verified by the government reached 17,491 islands. Thus, it is not surprisingly that Indonesia is famous for its marine tourism potential.

Belitung Island is one of the islands in Indonesia which belongs to Bangka Belitung Islands province. It is divided into two regencies, namely Belitung Regency 
and East Belitung Regency. Belitung Island is famous for its marine tourism. One of them is Tanjung Tinggi beach located in Tanjung Pandan city.

Tanjung Tinggi beach becomes more popular and well known by tourists when used as a shooting location for movies entitled "Laskar Pelangi" in 2008 and "Sang Pemimpi" in 2009. The movies portray how local people life on Belitung Island. The film achieved a great success in Indonesia which at the same time it promotes Belitung Island to be well known in a wider community. The number of visitors has increased from year to year either from domestic and foreign tourist. Until the end of August 2019, the number of archipelago tourists visiting Belitung is 191,392 people while foreign tourists reach 9,342 people. Belitung Island has one of unique landmark icons namely "Parang Tenggiri" which represents the way of people life in Belitung. Mostly, livelihoods of the local people are Fisherman \& Gardening. Fishermen are represented in the word "TENGGIRI" \& Gardening is described as "PARANG".

Fish gangan is one of the most beloved traditional foods by local people on Belitung Island. The raw materials of this food are related to livelihood culture of the local people namely "Parang Tenggiri". Thus, the traditional food of fish gangan is very potential to be determined as an icon of gastronomic tourism from Belitung Island. According to Taqwani (2012: 55) Gastronomy is a study of relationship between culture and food at which cultural aspects within a food are studied further. Therefore, the author is intended to conduct a research entitled "Traditional Fish Gangan: An icon of Gastronomic Tourism from Belitung Island"

Generally, this study aims to answer some following research questions:

a. What is the history, traditions and philosophy of fish gangan as a traditional food from Belitung Island?

b. How to make fish Gangan? c. what is strategy to make Traditional fish Gangan famous as an icon of Gastronomic tourism?

The limitations of in this study are as follows:

a. This research was conducted in Belitung Island

b. This research is focused on history, tradition, philosophy, making process, and strategies to promote Fish Gangan as a gastronomic tourism icon from Belitung Island

The purpose of this study was to obtain the following results:

a. Describe the history, traditions and philosophy of Traditional Fish Gangan from Belitung Island

b. Describe the process of making traditional fish Gangan.

c. Describe the strategy to promote this traditional food as a gastronomic tourism icon.

This study is expected to give some benefits from following aspects:

a. This research is expected to reach insight in the field of tourism and gastronomy.

b. For academics, it can be used as source to explore further information and studies about tourism and gastronomy especially in Belitung Island.

\section{Literature Review}

\subsection{Tourism}

Tourism is one of strategy industries in the world since many countries in the world receive great income from tourism sector. Tourism is also a strategic sector that supports economic and socio-cultural development since it encourages job vacancy, attract foreign investments, improve local people's income, and quality of a community, and also instill a sense of patriotism towards the nation's cultural values. (Suyitno, 2013: 68), http://ejournal.stipram.net/ Volume 7 Number 2 May 2013. 


\subsection{Attractions and Travel Attractions}

According to Sunaryo (2013: 25), in simply, attractions and tourist attractions are often classified based on their types and themes usually divided into three types namely: natural attractions, cultural attractions, and tourist attractions. Types of tourist attractions have a very significant impact on tourism products around the location. The tourism products is also made as an effort to attract tourists to visit the destination.

\subsection{Cultural Tourism}

Cultural tourism trips according to Pendit (2006: 38) is done to broaden a person's view of life through visiting different places either local or abroad by studying the local people's condition, habits, customs, way of life, culture, and art. In some cases, during their trips, people take opportunities to join cultural activities of the local people such as art exhibitions (dance, drama, music and sound) and learn historical backgrounds of the place. This kind of cultural tourism is the most popular tourism type in our country. It is commonly known that many foreign tourists come to Indonesia since they are interesting to see and know our rich culture, arts, customs and traditions.

\subsection{Gastronomy}

Gastronomy is a relationship between culture and food that cultural component becomes a main lens to learn about the food (culinary arts). However, scope of gastronomy is not limited at understanding food in terms of cultural aspects and region assets (Nurwitasi, 2015). Antón Clave and Knafou (2012: 4) added characteristics of gastronomic tourism as follows: 1) Gastronomy as an element and indicator of globalization; in particular, the affirmation of regional competition throughout the world 2) Tourists play a role in evolution of gastronomic tourism 3) Tourism is a main part of local gastronomic potential and it contributes to development of national and sub national identities 4) Gastronomic tourism is a tool to introduce culinary products as one of cultural products 5 ) The evolution of gastronomic tourism may become a pathway for tourism development 6) Gastronomy as a constructive element to establish tourist destination image7) Gastronomy as a travel destination 8) Gastronomy is an element of heritage under tourist dimension.

\section{Materials and Methods}

The method used in this research is descriptive qualitative. It is an approach to an in-depth description about human groups, an object, a condition or a thought. It is aimed to describe a condition in a systematic, actual, and accurate manner regarding a phenomenon (Nazir, 2005). Besides that, this study applied a qualitative research as the method.

The object of this study is a Traditional Food of Belitung Island namely Fish Gangan which is going to be promoted as a gastronomic tourism icon from Belitung Island. While the participants of this study are local people in Belitung Island.

Data collection technique in research is a way to obtain data needed to answer the research problems. There are several Data collection techniques applied in this study namely interviews, observation, documentation, and literature studies.

In this case, the authors use the study of literature as material from the research method by taking several sources of books and scientific journals as references to help collecting data in this research.

\section{Results and Discussion}

\subsection{Belitung Island}

Belitung is one of the islands in Indonesia that is a part of Bangka Belitung Islands province. This province has two districts namely Belitung Regency and East Belitung Regency. Belitung Island is famous for its beautiful marine tourism. 
One of the most famous attractions is Tanjung Tinggi beach.

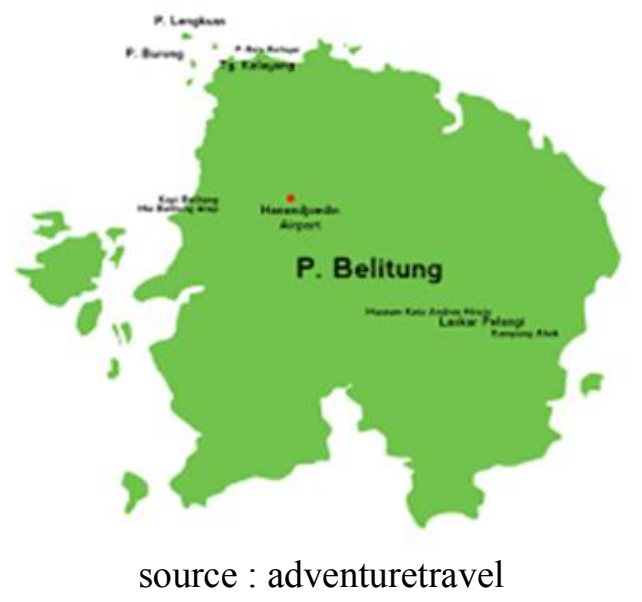

Belitung Island is not only famous for its marine tourism which has beautiful beaches but culinary of Belitung Island also diverse and rich of taste. There are a lot of seafood and plantation products from the local community which become main culinary of Belitung. Malay and Chinese ethnic traditions are mixed in Belitung culinary so that the culinary is very diverse and rich.

\subsection{Fish Gangan}

Fish Gangan is one of the most wellknown foods among the local people on Belitung. It is a kind of soup with a mixture of sour and spicy taste but Fish Gangan can also be cooked in stir-fry. The food is like a heritage introduced from one generation to a younger generation so that this traditional food has a great potential to be an icon of Belitung gastronomic tourism

\subsubsection{History and Philosophy of Traditional Fish Gangan}

The history and philosophy of traditional soup of Fish Gangan can not be separated from the background of local people which rely on fishing and gardening as their main livelihoods with the landmark "Parang Tenggiri". Fishermen are described as "TENGGIRI" \& Gardening is described as "PARANG".

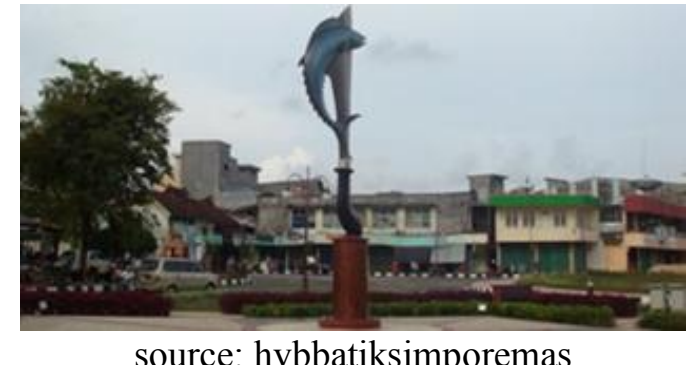

source: hvbbatiksimporemas

This traditional soup of fish Gangan is very famous and becomes favorite cuisine among local community on the island. The recipe and information about how to make this food are obtained from one generation to another one. The taste of this soup really represents a strong image of Malay flavor. There are several characteristics of fish gangan as follows. At a glance, its appearance is similar to curry but it does not use coconut milk. It is identical with the yellow color obtained from natural color of turmeric as one of the ingredients. It has a strong taste of sour and spicy with pieces of young pineapple as topping.

Fish gangan also can be cooked in a different way made as sautéed fish gangan. Of course, the main raw material of this food is fish and it can use any type of fish such as red snapper, ketarap fish, round fish, kerisi fish, mackerel fish and so on. This traditional cuisine has a good nutritional composition especially a high protein. Protein is very good for our bodies and growth of brain cells. While the food seasonings also consist of traditional herbs which can maintain human immunity such as turmeric, onion, garlic, etc. 


\subsubsection{Process of Making Traditional Fish Gangan}

\subsubsection{Traditional Fish Gangan}

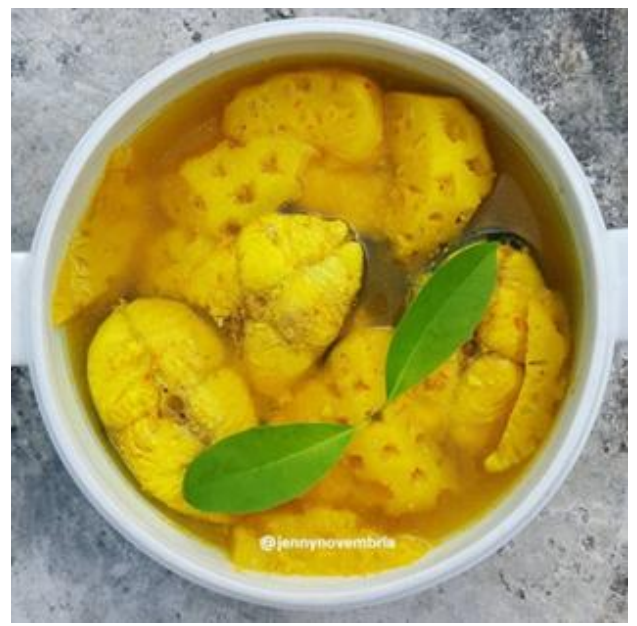

Source: travelingyuk.com

Ingredient :

- 500 grams of fish (according to taste), clean, cut into pieces

- $750 \mathrm{ml}$ of water Add fish and pineapple,

- 1 half-cooked pineapple, peeled, sliced Softened Seasoning :

- $7 \mathrm{~cm}$ warm turmeric.

- 15 red cayenne peppers

- 1 tsp shrimp paste

- 1 lemongrass stalk, take the white part, sliced

- 5 red onions

- $4 \mathrm{~cm}$ galangal

- salt

How to Make:

a. Boil the water with all softened seasoning. Add fish and pineapple, stir and cook again until the spices are well absorbed and cooked.

b. Lift and serve while warm.

Note: for making variation of sautéed fish gangan, the overall ingredients and steps to do are quite similar but the softened seasonings are sautéed with vegetable oil. Besides, it also uses a less water.

\subsection{Traditional Fish Gangan Becomes a Gastronomic Tourism Icon from Belitung Island}

Traditional fish gangan is very popular among the local community of Belitung Island. The recipe is inherited from one generation to another. Thus, this traditional fish food should be an icon of gastronomic tourism from Belitung Island. The tourists not only can enjoy the taste of this food but also learn historical background behind the food.

Traditional fish gangan can be conceptualized as a gastronomic tour package with eating in a Bedulang style. Bedulang is a distinctive style of eating food from Belitung. The process of eating is done by sitting in a group consisting of four people with sitting cross-legged and facing each other. The dish is served and enjoyed with certain procedures and ethics as can be seen in the following picture.

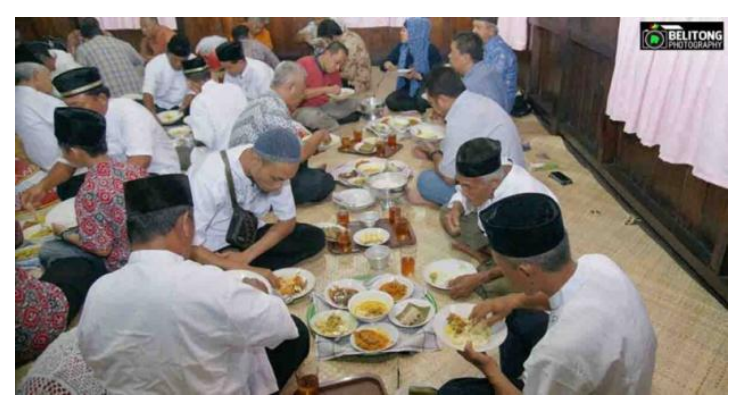

Source: travel.belitongekspres.co.id

\section{Conclusions}

Belitung is one of the islands in Indonesia which has a very beautiful marine tourism. However, Belitung Island also has a culinary potential that is interesting to be tourist attractions. Fish Gangan is one of Belitung traditional foods which is very beloved and famous among the local people. By conducting this research, the author expects that this traditional food can be promoted as a gastronomic tourism icon from Belitung Island. In addition, it is also expected that the food can be known by wider community so this traditional food keep sustainable and maintained. 


\section{References}

Antón Clave, S., \& Knafou, R. (2012). Gastronomy tourismand globalization.Paris:Arah Kebijakan Pengembangan Pariwisata Sumatera Selatan, 2019

Firmani, S. N., Turgarini, D., \& Putra, M. K. (2018). Pelestarian Kudapan Kalua Kulit Jeruk Sebagai Warisan Gastronomi Sunda di Ciwidey Jawa Barat. Gastronomy Tourism Journal, 5(1), 35-51.

Kartika, T., \& Harahap, Z. (2019). Pengembangan Kuliner Pempek Sebagai Data Tarik Wisata Gastronomi di Palembang Sumatera Selatan.

Moch.Nur Syamsu.2018. Studi Kelayakan Air Terjun Nggembor sebagai Destinasi Wisata untuk Meningkatkan Perekonomian Masyarakat Desa Jatimulyo, Kecamatan Girimulyo, Kabupaten Kulonprogo, Yogyakarta. Jurnal Kepariwisataan, Vol 12, No. 3 (2018): 71-84 http://ejournal.stipram.net/

Nazir, M. (2005). Metode Penelitian. Bogor: Ghalia Indonesia

Nurwitasri, A. (2015). Pengaruh Wisata
Gastronomi makanan tradisonal Sunda terhadap Keputusan Wisatwan Berkunjung ke Kota Bandung. BARISTA (Volume 2, Nomor 1, Juli 2015)

Nyoman S. Pendit. Ilmu Pariwisata. PT Pradnya Paramita. Jakarta. 2006. Hal 38

Taqwani, M.D. 2012. A-reseaerch.upi.edu. Analisis Kebudayaan Gastronomi dan Tindak Tutur dalam Kajian Pragmatik pada Film Ratatoulie,55

Pakpahan, R., \& Kristiana, Y. (2019). Pengenalan Kuliner Tradisional Sebagai Daya Tarik Wisata Belitung. Prosiding Konferensi Nasional Pengabdian Kepada Masyarakat dan Corporate Social Responsibility (PKM-CSR), 2, 1054-1060.

Sunaryo ,Bambang .2013. Kebijakan pembangunan destinasi pariwisata konsep dan aplikasinya di Indonesia .Yogyakarta : GAVA MEDIA

Suyitno. 2013. Pengembangan Potensi Kepariwisataan di Kabupaten Sleman Daerah Istimewa Yogyakarta. Yogyakarta. http://ejournal.stipram.net/ Volume 7 Nomor 2 Mei 2013 